\title{
Angiomyofibroblastoma of Vulva
}

\author{
Emel Kurtoglu ${ }^{1}$ Rabia Kaya², Nevin Topak ${ }^{3}$
}

\section{ABSTRACT}

Angiomyofibroblastoma is a rare,benign,well-circumscribed neoplasm predominantly occurring in the pelviperineal region of middle-aged women. The tumour cells are round-to-spindle shaped concentrated around vessels. They almost have immunoreactivity for desmin and vimentin, consistently positive for estrogen and progesterone receptors,occasionally positive for CD 34 . The complete surgical excision of the tumour is necessary. It is important to distinguish this tumour from especially aggressive angiomyxoma to avoid inadequate treatment. Here, we report a case of vulvar angiomyofibroblastoma in a 46-year old postmenopausal woman whose findings were differentiating from others. Histologically, the tumour involved fibroadipose tissue and immunoreactivity for desmin and actin was negative.

Key words: Angiomyofibroblastoma, vulva, postmenopause

\section{Vulvanın Anjiomyofibroblastoması}

\section{ÖZET}

Anjiyomiyofibroblastom, genellikle orta yaș kadınlarda,pelviperianal bölgede ender olarak görülen,çok iyi sınırlı selim bir tümördür.Tümör hücreleri damarlar etrafında iğsi daireler șeklinde yerleșmișlerdir.Hemen her zaman desmin ve vimentin,sürekli olarak östrojen ve progesteron reseptörleri için olmakla birlikte bazen de CD 34 için immünreaktiftirler.Cerrahi tedavide tam ekzisyon gereklidir.Yetersiz tedaviden kaçınmak için,tümörü agresif anjiyomiksomdan ayırt etmek oldukça önemlidir.Burada,46 yaşında postmenopozal dönemdeki bir kadın hastada,farklı histopatolojik bulguları olan bir vulvar anjiyomiyofibroblastom olgusu sunulmaktadır.Tümör hücreleri fibrodipoz doku içermekte ve desmin ve aktin için negatif immünreaktivite göstermektedir.

Anahtar kelimeler: Anjiyomiyofibroblastom, vulva, postmenopoz

\section{INTRODUCTION}

Angiomyofibroblastoma (AMFB) is a rare, well-circumscribed mesenchymal neoplasm, usually arising in the pelviperineal region, especially the vulva and apparently composed of stromal cells distinctive to this anatomic region (1). It was first described by Fletcher et al. in 1992 as a new entity (2). This tumour arises predominantly in females, principally in adults between menarche and menopause (2-6). Ten percent (10\%) of patients are postmenopausal and rare cases occur in males which are defined as male angiomyofibroblastoma-like tumour $(2,6)$. Most cases present as a slowly enlarging, painless, circumscribed mass and are often misdiagnosed as a Bartholin's gland cyst and hydrocele of the canal of Nuck $(7,8)$. These lesions are well-circumscribed but not encapsulated with a thin-pink cut surface and soft consistency (1). Histologically, these tumours show varying cellularity with prominent vessels. The vessels are mostly small, thin-walled, ectatic and are set in an adundant loose, oedematous stroma. The tumour cells are round-to-spindle shaped with eosinophilic cytoplasm and typically are concentrated aroud vessels. Mitosis are rare (1). The majority of cases have immunoreactivity for desmin and vimentin. They are consistently positive for estrogen and progesterone receptors, occasionally positive for CD 34 and negative for $\mathrm{S} 100$ protein, keratin and fast myosin $(9,10)$. The recommended treatment is complete surgical excision of the tumour. Although these tumours doesn't tend to recur locally, follow-up examination is necessary (9). Histopathological differential diagnosis include cellular angiomyofibroma, aggressive angiomyxoma, myxoid li-
${ }^{1}$ Departments of Obstetrics and Gynecology and ${ }^{2}$ Pathology,Eregli,Konya,Turkey ${ }^{3} \mathrm{D}$ epartment of Pathology, Karaman,Turkey

Received: 01.07.2011, Accepted: 24.08.2011
Correspondence: Dr. Emel Kurtoğlu Ereğli Devlet Hastanesi, Ereğli, Konya 


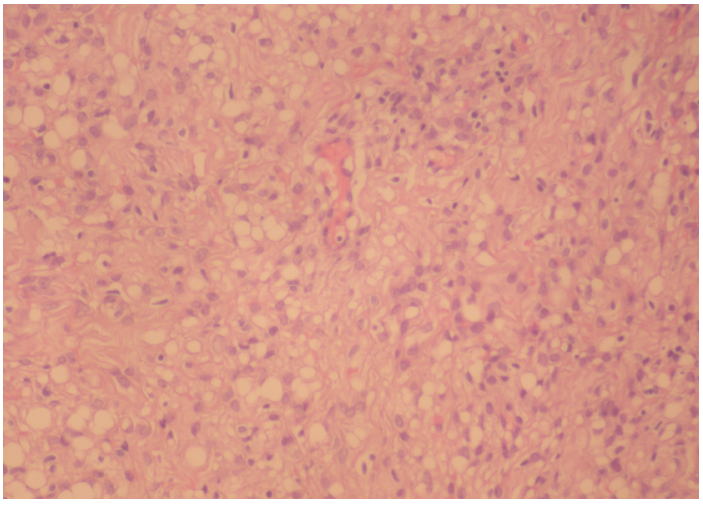

Figure 1. Capillary structure and scattered adipocytes (H/E X40)

poma, myxoid liposarcoma and myxoid neural tumours (11-13). Here, a case of angiomyofibroblastoma is presented.

\section{CASE}

A 46-year-old postmenopausal woman presented with a painfull, slow- growing vulvar mass. The patient gave a history of small nodular mass in her vulvar region starting nine years before, which had grown slowly and became painfull during the last two months. On physical examination, a soft, mobile and painfull mass, measuring almost $4 \times 3 \times 2 \mathrm{~cm}$, was seen in the left labia majora. The patient had no medical and family history of note except being a hepatitis $B$ carrier. There was no abnormality on vaginal examination, pelvic ultrasonography imaging and laboratory examination. A simple tumour

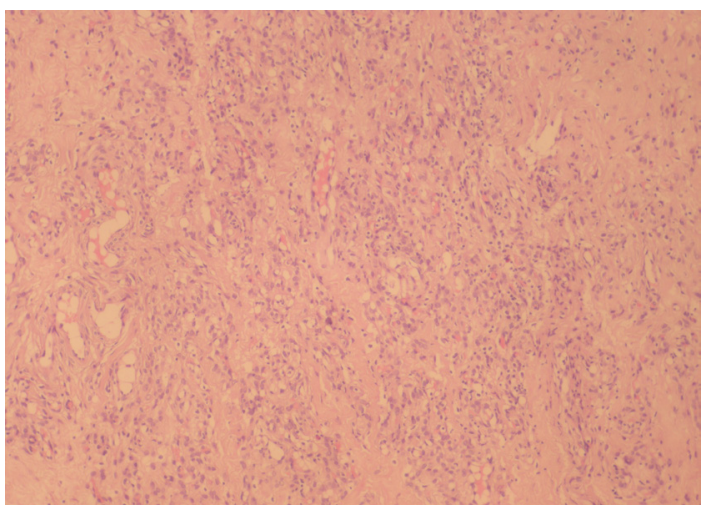

Figure 2. Vascular and capillary-like structure in a loose matrix (H/E X20)

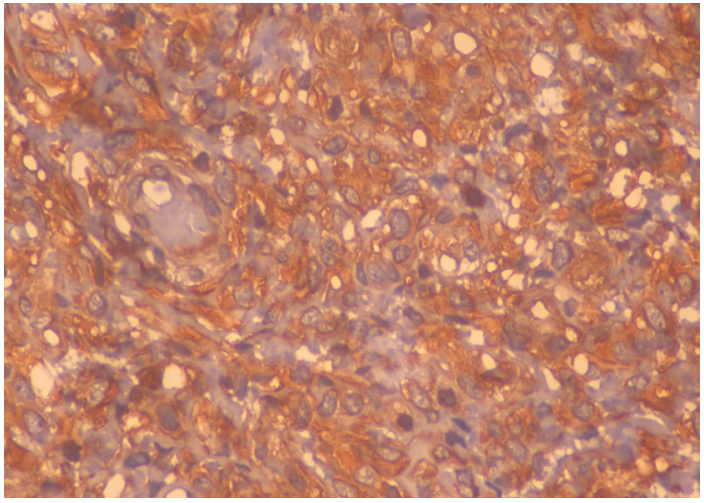

Figure 3. Strong and diffuse vimentin positivity (Vimentin $\times 40$ )

excision was performed to the patient. Macroscopically, the resected tumour had a brownish soft appearance, measuring $3 \times 4 \times 3 \mathrm{~cm}$. Microscopically, fibroadipose tissue (Figure 1), having hypo-and hypercellular areas with capillary blood vessels and mast cells were seen (Figure 2 ). There was no atypical mitosis. In immunohistochemistry, tumour cells were strongly positive for vimentin (Figure 3), CD 34 (Figure 4), estrogen and progesterone receptors, focal positive for $\mathrm{S}-100$ protein and negative for desmin, actin and pancytokeratin. The index of Ki 67 in cellular areas was $4 \%$.

\section{DISCUSSION}

AMFB is a rare and usually benign mesenchymal tumour that predominantly involves premenopausal women, but we report a 46-year-old postmenopausal patient

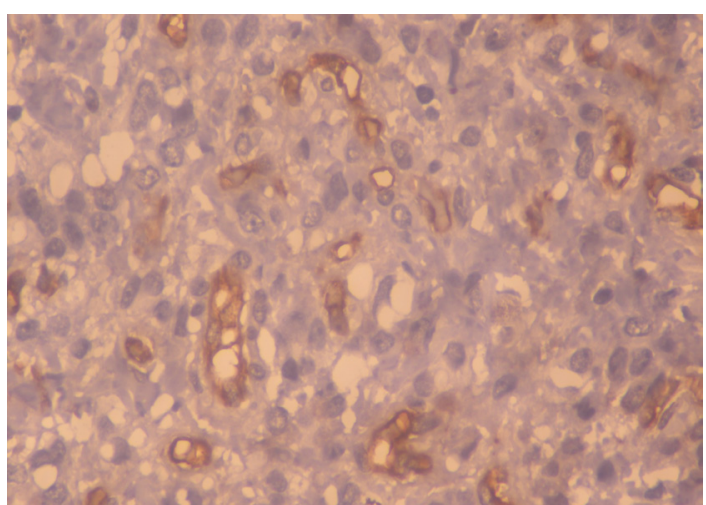

Figure 4. Endothelial cells are positive for $C D 34$ (CD $34 X 40)$ 
who presented with a vulvar AMFB. The tumour has a predilection for lower genital tract of women and men, especially for the vulvar region as in the our patient. But unusual regions of female and male can be involved like fallopian tube, perianal region, retroperitoneal and male inguinal region $(8,10,12,14)$. Most cases measure less than $5 \mathrm{~cm}$ in maximum diameter, as in the our case, although rare examples measuring up to $10 \mathrm{~cm}$ have been recognized (1). Nagai $\mathrm{K}$ et al. reported a huge pedunculated AMFB of the vulva at a 48-year-old woman, which was $23 \mathrm{~cm}$ in diameter and weighed $4534 \mathrm{~g}$ (4). There are only a few case reports of huge AMFB in the literature $(9,16)$. Angiomyofibroblastoma has characteristic histomorphologic features and shows myofibroblastic differentiation. The tumours are generally well demarcated by a thin fibrous pseudocapsule and have alternating hypo-and hypercellular areas with abundant thinwalled blood vessels which were surrounded by stromal cells within an oedematous to collegenous matrix (9). Ten percent $(10 \%)$ of cases have a variably prominent well differentiated adipocystic component in postmenopausal patients as in our patient (1).Immunoreactivity for desmin and vimentin is detected in the majority of tumour cells, which are consistently positive for estrogen and progesterone receptors $(1,9)$. But in postmenopausal women, desmin staining may be reduced and absent, and also in pregnancy, the tumour cells can be negative for estrogen and progesterone receptors $(1,13)$. In our case, immunoreactivity for desmin was negative, too. As some cases show morphologic overlap with cellular angiofibroma and aggressive angiomyxoma, it is too important to recognize AMFB and distinguish it from other overlapping tumours, especially aggressive angiomyxoma to avoid inadequate treatment. AMFB is entirely benign, does not recur locally, even after marginal local excision although agressive angiomyxoma has a local recurrence rate of approximately $30 \%$ and has a rare metastatic potential $(1,16,17)$. We have had no involvements that might raise the question of bias in the work reported or in the conclusions, implications or opinions stated.

\section{REFERENCES}

1. Fletcher CDM, Angiomyofibroblastoma. In Fletcher CDM, Unni KK, Mertens F, eds. WHO Classification of Tumours. Pathology and Genetics of Tumours of Soft Tissue and Bone. Chapter 2: Fibroblastic/myofibroblastic tumours. Lyon: IARC Press 2002: 71-2

2. Fletcher $C D$, Tsang WY, Fisher C, Lee KC, Chan JK. Angiomyofibroblastoma of the vulva. A benign neoplasm distinct from aggresive angiomyxoma. Am J Surg Pathol 1992; $16: 373-82$

3. Fukunaga $M$, Nomura $K$, Matsumoto $K$, Doi $K$, Endo Y, Ushigome S. Vulvar angiomyofibroblastoma. Clinicopathologic analysis of six cases. Am J Clin Pathol 1997; 107:45-51

4. Laskin WB, Fetsch JF, Tavassoli FA. Angiomyofibroblastoma of the female genital tract: analysis of 17 cases including a lipomatous variant. Hum Pathol 1997;28:1046-55

5. Nielsen $G P$, Rosenberg $A E$, Young $R H$, Dickersin $G R$, Clement $P B$, Scully $R E$. Angiomyofibroblastoma of the vulva and vagina. Mod Pathol 1996;9:284-91

6. Ockner DM, Sayadi $H$, Swanson PE, Ritter JH, Wick MR. Genital angiomyofibroblastoma. Comparison with aggressive angiomyxoma and other myxoid neoplasms of skin and soft tissue. Am J Clin Pathol 1997;107:36-44

7. Canales BK, Weiland D, Hoffman $N$, et al. Angiomyofibroblastoma-like tumors (cellular angiofibroma). Int J Urol 2006;13:177-9

8. Perko Z, Durdov MG, Druzijanic N, Kraljevic D, Juricic J. Giant perianal angiomyofibroblastoma-a case report. Coll Antropol 2006;30:243-6

9. Barat S, Tirgar-Tabari S, Shafaee S. Angiomyofibroblastoma of the vulva. Arch Iran Med, 2008;11:224-6

10. Quintero C, Sasken $H$, Houck KL, Hernandez $E$. Angiomyofibroblastoma of the retroperitoneum:a case report. J Report Med 2007;52:741-4

11. Micheletti AM, Silva AC, Nascimento AG, Da Silva CS, Murta EF, Adad SJ. Cellular angiofibroma of the vulva:case report with clinicopathological and immunohistochemistry study. Sao Paulo Med J 2005;123:250-2

12. Ito M, Yamaoka H, Sano K, Hotchi M. Angiomyofibroblastoma of the male inguinal region. Arch Pathol Lab Med 2000;124:1679-81

13. Cetinkaya K, Al RA, Gursan N. Angiomyofibroblastoma of the vulva during pregnancy. J Obstet Gyneacol Res 2011;37: 1162-5

14. Kobayashi $T$, Suzuki $K$, Arai $T$, Sugimura $H$. Angiomyofibroblastoma arising from the fallopian tube. Obstet Gynecol 1999;94:833-4

15. Nagai $K$, Aadachi K, Saito H. Huge pedunculated angiomyofibroblastoma of the vulva. Int J Clin Oncol 2010;15:201-5

16. Fetsch JF, Laskin WB, Lefkowitz M, Kindblom LG, MeisKindblom JM. Aggressive angiomyxoma: a clinicopathologic study of 29 female patients. Cancer 1996;78:79-90

17. Granter SR, Nucci MR, Fletcher CD. Aggressive angiomyxoma: reappraisal of its relationship to angiomyofibroblastoma in a series of 16 cases. Histopathology 1997;30:3-10. 